\title{
Strengthening the Political Ethics of Pancasila in Making Good Governance
}

\author{
Edi Kusnadi \\ Civic Education, FKIP \\ Universitas Islam Nusantara \\ Bandung, Indonesia \\ edi.kusnadi@ fkip-uninus.ac.id
}

\author{
Eneng Martini \\ Civic Education \\ STKIP Pasundan \\ Cimahi, Indonesia \\ enengmartini@student.upi.edu
}

\author{
Mahmud Mahmud \\ Civic Education \\ STKIP Kusuma Negara \\ Jakarta, Indonesia \\ mahmud@student.upi.edu
}

\begin{abstract}
Whether or not realized the realities of political praxis that leads to the dimension and space that seemed to be free value (value free), putting aside ethics / moral, so far from the practice of politics in accordance with the values of the philosophy of the Indonesian nation itself, this indicates weakness political practices that are in line with political ethics. In terms of values, morals and ethics in politics are closely related to each other. Political ethics should be interpreted as a science that discusses the principles of political morality. Thus, the values of morality contained in Pancasila play a role in the realization of a good political ethics system in this country. The weakness of political ethics can be seen from various actions deviate from the legal order that occurred in Indonesia, deviant acts as if it has been institutionalized in the community and has become a public secret. Even for officials such as obligations, and even considered perverted if not doing dirty deeds. Moreover, discussing the formulation of policies, we have recently heard the term "Order Article" which does not reflect the ethics of good governance. It thus has certain implications for good governance and dignity management. In terms of Good Governance is a concept offered by the democratic system to become a best solution. But at the level of practice in the field, far from the expectations of good governance, consequently accountability, transparency, government integrity into a big question to be evaluated so that the strengthening of political ethics is a very urgent need for the realization of governance in accordance with the values of ethics Pancasila.
\end{abstract}

\section{Keywords_- political ethics; good governance; democracy}

\section{INTRODUCTION}

Political ethic practices are a desperate need in order to realize good governance in accordance with the expected good at central and regional level for the sake of the purity of a civilized democracy in accordance with the ethical values of Pancasila and the Constitution of the Republic of Indonesia.

Political practice should display the figures that are pure yield ethical values and moral Pancasila as the driving political system in Indonesia, it is therefore the duty of all parties to maintain, preserve, practice and maintain ethical and moral Pancasila in the political sphere a State of Indonesia, thereby ensuring value -the value of Pancasila that exudes charisma civilization adorn the political life of the nation and state in the Republic of Indonesia.

Because basically ethical political practice has a specific purpose in a good government as a No.VI MPR decree in 2001 that: "Political Ethics and Government intended to establish a clean government, efficient, and effective, and foster a democratic political atmosphere that characterized by openness, a sense of responsibility, responsive to the aspirations of the people, respect differences, honest competition, the willingness to accept a more correct opinion, and uphold human rights and the balance of rights and obligations in the life of the nation. Ethical governance mandates that state officials have a taste of the high interest in providing services to the public, ready to resign if it felt he had violated the norms and value systems or be unable to fulfill the mandate of the people, nation and state. Potential problems that could lead to hostility and antagonism settled amicably with the full knowledge and wisdom".

Unfortunately, the political practice of late not to reveal the face towards improving and ensuring the values of civility Pancasila contained in MPR decrees that, it is inverted to deviate from nature turned into a political practice that is not ethic not based on the principles of political ethics that should even betrayed purity values of Pancasila ethics itself. It can be seen from the rise of political practices that are far from the values of ethics say and to do a lie as a habit and strategy in taking and maintaining a power. The fragility of the sacred mission of national ideology in politics as if it has become a disease that can not be cured with a variety of existing regulations,

In terms of the MPR is very clear that: "Political Ethics and Governance contains missions to every official and political elite to be honest, trustworthy, fair, ready to serve, highminded, having exemplary, humble, and be prepared to resign 
from public office if they are proven guilty and morally discretion contrary to the law and sense of justice. This ethic is embodied in the form of attitude manners in a tolerant political behavior, do not pretend, not arrogant, far from being hypocritical and not lying to the public, not manipulative and various other laudable actions [1].

With an indication of the weakening of the ethic political practices on these elites give the space an impact on governance is not good away from good governance. For good governance has its own indicators so that if the indicators are in good governance was maintained then it will look wheels good governance anyway.

Therefore, ethic political practices in accordance with the values of Pancasila is a solid foundation in the creation of governance is good, what does not, in good governance for good indicator of which is the rule of law, transference, visionary strategic and this is a translation of the values contained in Pancasila.

An attempt to revitalize the political ethics of Pancasila in political practice should be an important agenda to be addressed from various dimensions of life such as: dimensional orientation of the education system National effort to revitalize the Citizenship Education as the core education political ethics Pancasila, the planting of political education for every citizen (cadres of political parties), the establishment of good interaction between society, government and the private character of Pancasila planting.

\section{DISCUSSION}

Before going deeper, we discuss about the polarization of political ethics Pancasila to realize Good Governance, here we peeled first starting from ethics, politics, political ethics, political ethics Pancasila, and Good Governance.

\section{A. Ethics}

Ethics is a critical and fundamental thinking about certain teachings and moral views. According Rosenbloom ethics can be regarded as a form of self-accountability or "inner check" of the behavior of public administrators [2]. Ethics is a statement, written or oral, which prescribe or forbid certain behavior in certain conditions Nigro and Nigro [3]. In this case ethics is also a doctrine about why and how we must adhere to a certain moral system. There are two groups of ethics known the general ethics and special ethics. Some understanding of ethics as follows:

- General ethics is questioning the ethics principles that apply to every human action in general.

- On the other hand, special ethics deals with the relation or application of principles in general ethics in relation to the field of human life. This special ethics is divided into two parts, namely individual ethics and social ethics.

- Individual ethics is the application of ethical concerns myself obligation to comply with the concept of right and wrong are arranged in individual ethical system.
- While social ethics is a human duty to apply the ethics of another human being in the society in accordance grip humans as social beings

Why ethics increasingly needed in Indonesia? There are some things on which to base the necessity of ethics developed in Indonesian society today Suseno [4], Among others:

- The condition of society is increasingly pluralistic, including in the field of morals. Nowadays everyone is faced with many moral views are often contradictory. Which one to follow? Moral of the parents? Traditional moral or village? Moral or offered through the mass media?

- Indonesian society is in the era of transformation without equal. The transformation took place under the force of power that affects all aspects of people's lives, the wave of meditation. In the transformation of the social economy, intellectual and cultural, for example, the Indonesian nation is challenged with the notions of liberalism, secularism, hedonism, materialism, etc. In this situation ethics can help to Indonesian people not to lose orientation, can distinguish between what is essential and what can be changed and thus still be able to take on attitudes that can be accounted for.

- Not surprisingly, that the process of social change and moral culture is used by various parties to "fish in troubled waters". This situation is exploited by the unscrupulous to offer their ideologies as rescue medications, whereas reality only as a means for profit only. Decentralization is enlivened / socialized by political elites even though the reasoning reason is really in accordance with the needs of the community, such as the efficiency and effectiveness of services, but behind all the reasons is inseparable from the objective of the elites to get a large share of the funds from the central government. In this case the ethics of helping someone to not naive or extreme in the face of new things.

\section{B. Political ethics}

Political word is not foreign to us to hear that some people still feel politically taboo words will not even care what it is politics, politics existing in the State of Indonesia is still very far from what was expected. Whereas in politics there is an ethic in practice especially Pancasila highly political ethics we are proud to get a good governance (good governance). Pancasila is an ideology and outlook of the nation of Indonesia, Pancasila contained in the values governing the life of the nation state in order to create a peaceful, just, prosperous and peaceful. Likewise, with Pancasila set about ethics in politics, because politics without ethics will occur chaotic life of the nation.

While the meaning of political ethics is one branch of ethics that is applied in the political environment or the political dimension of human life. Above we mentioned that the ethical concerns completely wrong moral measures a man's actions, and it contains a value as follows: 
- Political ethics questioned the ethics of human responsibilities and obligations as it should and humans as citizens to be obedient to the laws in force in the country.

- Talking about the function, the function of political ethics in society is being the provider of value or theories that explain the truth or falsity of an act in relation to the political legitimacy.

- Source values are clear, so that the determination of right or wrong an action is no longer based on emotions, prejudice, or a priori, but objectively and argumentative.

Even so, the political ethic is not directly interfering in the affairs of practical politics. In Indonesia, where political ethics, based on Pancasila to task of political ethics to ensure the ideological discussion of the problems can be carried out objectively. Ideological problem in question is a problem with regard to the legal and political power. Pancasila used as an option as the basis of life of citizenship or also called as the basis of political life, it is thus not politically neutral, but must be based on ethical values. And this is one of the tasks of political philosophy that is to enlighten the meaning of politics and explicit ethical values in politics based on Pancasila.

For now, we often see political actors who cannot act in accordance with the example of Pancasila as political ethics. there are still many political ethics violations that occurred in Indonesia. As an example of the violation of political ethics that occurred in Indonesia include: the officials involved in corruption, the unscrupulous law enforcement and the courts are taking bribes, political elite tangled case but in living he gets special treatment during the judicial process and serving a sentence, dawn raid or gratuity under the guise of social work carried out by the prospective political officials often we hear also with the name of dowry it is no stranger we hear in the political world,

\section{Political ethics Pancasila}

Pancasila political ethics are ethics that comes from noble values of Pancasila which should be the only in creating a mechanism of political system in Indonesia, as well as a political force in the form of the spirit of the organizers of the State. Because of this spirit to emerge as a nation and a state ethics, where the position of Pancasila as the source of such ethics [5].

Political ethics a part of the philosophy of political science that provides an ethical foundation to the political system to conform to the values and goals of the nation state ethics or moral philosophy (Telchman,1998) have explained the purpose of good and evil. Political ethics thus has the purpose of explaining where political good behavioral and vice versa. What good standard? According to Al-Muchtar Standard in both the political context is how politics is directed to advance the public interest. This means that if politics has led to certain personal and group interests, it indicates a bad political ethics. It should be understood that our nationalism will only flourish in a democracy is, when Pancasila used as a reference in political ethics. Political ethics could walk if there is respect for humanity and justice happen. This is a basic precondition that needs to be referenced together in formulating a democratic politics-based ethics and morality [5].

Political ethics is needed, especially in a variety of political action that ethics against political actors can be strengthened and that is not being destroyed. The protective function of the people did not go as commitment. Destroyed public civility is what often damage the face of law, culture, education and religion. The destruction of these joints makes faces hazy future of this nation. The lack of street politics can be caused by the weakening of the ethical dimension of politics, whereas disputes occur unresolved resulting in the blurring caused by political ethics is not used as a reference in political life.

The weakening of political ethics can occur in a different campaign promises with implementation. That is only given hope without realization. This is what makes the public taught to apply the orientation of life to find it easy. Circumstances we truly lost the power to renew itself. Political ethics which is based on Pancasila can be destroyed by politics is synonymous with money, money is the deciding everything in the public space.

In politics that has the robustness of political ethics as perceived as one of the weaknesses of reform is the multiplicity of all-effects, the taps of change orientation are stronger and very hate the old system without testing that which is better. Thus, it is feared there is a decline in political ethics of the elite in every trace journey.

The weakening of political ethics and political elite actors is one of them marked by the prominence of the attitude of pragmatism in political behavioral are only concerned with the group only. The interests of the nation according to them can be built only through the group. And each group to think so. The implication is necessary to develop the strength of the political system, by strengthening the basic ethical values based on the values of Pancasila transcendental [5].

When the weakening of political ethics will display the degrading political behavioral of political and political actor. The emergence of money politic cases, money raids at dawn, political dowries, political mafia, power brokers or posts.

\section{Good Governance}

As for the characteristics of a good governance system (the characteristics of good system of governance) by the United Nations Development Program (UNDP) in the first paper mentioned that; "Legitimacy, freedom of association and participation and freedom of the media, fair and established legal frameworks that are enforced impartially, bureaucratic accountability and transparency, freely available and valid information, effective and efficient public sector management, and cooperation between Governments civil society organizations" [6]. In addition to UNDP, as quoted by the Institute of Public Administration (LAN) as for the principles of good governance as follows:

- Participation; every citizen has a voice in decisionmaking, directly or through mediation legitimacy of the institutions that represent their interests. The principle of participation is a form of participation of citizens in decision-making, either directly or through legitimate 
representative institutions based on democratic principles of the freedom to assemble and express opinions constructively. To encourage community participation in all aspects of development, including in the sectors of social life other than political activity, the regulatory bureaucracy should be minimized.

- Rule of Law; rule of law, decisions, government policies, organizations, business entities related to the public is based on the law. Principle of law enforcement is a professional governance must be backed by a law enforcement authority. Without sustained by the rule of law and its enforcement, consequently, public participation can be turned into a public action anarchist. The public needs firmness and legal certainty. Without the certainty and the rule of law, the political process will not run and well-ordered [7].

- Transparency; transparency is the free flow of information; it is known, monitored by many of the policies, processes governmental organizations institutions. According Masruri, the principle of transparency is another element that sustains the realization of Good and Clean Governance [7]. As a result of the absence of the principle of transparency, according to many experts, Indonesia have fallen into this quagmire of corruption is very severe. Not to repeat the past experience in the management of public policies, especially in economics, government at all levels should apply the principle of transparency in the public policy process. This is absolutely necessary in order to eliminate the culture of corruption among government, both central and implementing the underlying

- Responsiveness; government agencies must be responsive to their stakeholder interests. The principle is responsive is in the implementation of the principles of Good and Clean Governance that government must be responsive to the problems of society. Governments must understand the needs of the people and not wait for them to convey his desires, but the government should proactively study and analyze the needs of society.

- Consensus orientation; Oriented towards a deal that could mediate the different interests as a way of finding the best alternatives and defending the interests of the wider. The principle of consensus is that any decision should be made by deliberations by consensus. How to capture the consensus, but can satisfy everyone or most of the parties, this will bind most of the components are consulted and have the power to force (coercive power) against all those involved to implement the decision.

- Equity; equality of all citizens as well as male-female, regardless of the status of poor-rich, have the same opportunities to get welfare. The principle of equality (equity) is the similarity in treatment and public services. The principle of equality requires that any implementation of the government to act and behave fairly in terms of public services regardless of differences in faith, race, gender, and social class.

- Effectiveness and efficiency; each process activity, the activities of government agencies to accomplish its task in accordance with the line set. To support the principles mentioned above, good governance and clean also must meet the criteria of an effective and efficient, that is efficient and effective. Effectiveness criteria are usually measured by the parameters of the products can reach the maximum benefit of society from various groups and social strata. Meanwhile, the principle of efficiency is generally measured by the rationality of the construction costs to meet the needs of all communities. The smaller the cost of used for the benefit of the largest, then the government included in the category of efficient government.

- Accountability; decision makers in government, the private and the public sector (civil society) is responsible to the public and institutional stakeholders. The principle of accountability is the accountability of public officials to the people who gave him the authority to take care of their interests. Every public official is

- Required to account for all policies, deeds, moral, or neutralist stance towards society. This is what is required in the principle of accountability in the effort towards good governance and authoritative.

- Strategic vision; strategic vision, leaders and the public should have a good and far-reaching perspective on good governance and human resource development as needed for development.

According Soelendro, the main elements of this effort good governance is transparency, fairness, responsibility and accountability [8]. And according to Yunus, argues that the elements of good governance is the requirement of openness (transparency), increased efficiency in all areas (efficiency), clearer responsibility (responsibility) and fairness (fairness) [9]. So, good government in essence a modern and effective governance, which is a democratic government whose main elements of community participation.

The implementation of good governance is a key prerequisite to realize the aspirations of the community achieve the goals and ideals of the nation and the state. In order to this, required the development and implementation of appropriate government accountability system, clear and evident that governance and development can be efficient, effective and accountable and corruption-free. In this regard should be noted also that mechanisms for regulating accountability in government departments, and strengthen the role and capacity of the parliament and the availability of equal access to the public information.

\section{E. Strengthening Political Ethics Pancasila in realizing good governance}

In order to strengthen a political ethics of Pancasila which in turn will impact on good governance should be done from 
various dimensions, including: the dimension of the education system, the subjects (revitalization of Civic Education as the parent of ethics education politics), political education (formal institutions / informal / non-formal).

Indonesian national education system stipulated in Law No. 20 on National Education System, the substantive content of the law is clear that national education is education that is based on Pancasila and the Constitution of the Republic of Indonesia Year 1945 rooted in religious values, national culture of Indonesia and responsive to the changing demands of the times. This means that the issue of education as a whole regarding the kind of regulation, praxis instrument of education, infrastructure and so should principle on Pancasila and the Constitution of the Republic of Indonesia in 1945, the next is the revitalization of Civic Education as the parent of the nation's political ethics education in Indonesia.

In this case, as Al-Muchtar, Pancasila as the source of political ethics and civic education as a political ethics education should be developed on the basis of historical insight that provides a valuable lesson in the course of the independence of the State of Indonesia so closely embedded in nationalism and patriotism of citizens of the civilized and dignified [5].

Next important that the granting of political education either at formal institutions, informal and non-formal strengthen political ethics Pancasila integrated into Citizenship Education. Thus, the efforts to strengthen the political ethics of Pancasila in ensuring good governance will be achieved as well as the direction and purpose and ideals of the nation Indonesia is written in the Indonesian national goal is social justice for all Indonesian people.

\section{CONCLUSION}

Knowingly or not the reality of political praxis that occurs leads to the dimension and space as discretionary value (value free), leaving aside the ethical / moral, so far from ethic political practice in accordance with the values of the philosophy of the Indonesian nation itself, indicating weak political practices in accordance with the political ethics. In terms of values, morals and ethics in politics very closely related to each other. Political ethics must be understood as a science which deals with the principles of political morality. Thus, the moral values of Pancasila role in the realization of a good political ethics system in this country. The weakness of the political ethic can be seen from various perversity of the legal order that occurred in Indonesia, deviant act as if it has been institutionalized in the society and it is common knowledge. Even for officials such as an obligation, and it is considered aberrant if not done the dirty deed.

For that an effort in strengthening the political ethics of Pancasila is urged, as for such efforts among which the efforts: strengthening of the values contained in the national education system, the revitalization of Civic Education as the core of political ethics and the inculcation of political education to the citizens of the nation.

\section{REFERENCES}

[1] Tap MPR No. VI/ 2001 tentang Etika Kehidupan Berbangsa.

[2] Rosenbloom, D.H, Understanding management, politics and law in the public sector (2nd ed.). NJ, Random House Inc. 1989.

[3] Nigro, F.A, and Nigro, L.G, Modern public administration (7 th ed.). New York: Harper and Row. 1989.

[4] Magnis, F., Suseno. Etika Dasar. Masalah-masalah Pokok Filsafat Moral. Yogyakarta: Kanisius. 1993.

[5] Al-Muchtar, Suwarma, Ilmu Kewarganegaraan. Konstruksi Nilai Pancasila dalam Pendidikan Kewarganegaraan. Laboratorium UPI Bandung. 2017

[6] United Nations Development Programme (UNDP), Governance For Sustainable Human Development: A Undp Policy Document. 1997.

[7] Masruri, Good Governance And Clean Governance. STISIP Kartika Bangsa. Yogyakarta. 2014.

[8] Soelendro, Ari, Paradigma Baru Aparat Pengawasan Intern Pemerintah. Makalah, Kongres Nasional Akuntan Indonesia IV. Jakarta. 2000.

[9] Yunus, Hadori. Paradigma Baru Akuntansi Sektor Publik. Makalah Kongres Nasional Akuntan Indonesia IV. Jakarta. 2000. 